\title{
Analysis of Alignment between National Curriculum of Education and Textbooks at Higher Secondary Level in Punjab-Pakistan
}

\author{
Sobia Saher ${ }^{\text {a }}$, Najam-ul-Kashif ${ }^{\text {b }}$ \\ ${ }^{a}$ Ph.D. Scholar, Department of Education, The Islamia University Bahawalpur, Pakistan \\ Email: qamarmisbah99@gmail.com \\ ${ }^{\mathrm{b}}$ Assistant Professor, Department of Education, The Islamia University Bahawalpur, Pakistan \\ Email: drnajam.ulkashif@iub.edu.pk
}

\begin{tabular}{|c|c|}
\hline ART & ABSTRACT \\
\hline His & \multirow{9}{*}{$\begin{array}{l}\text { This study was conducted to identify the degree to which the objectives } \\
\text { of higher secondary level national curriculum of Education were aligned } \\
\text { with the textbooks in Punjab- Pakistan. The study was done by } \\
\text { reviewing the national curriculum of Education and Textbooks for grade } \\
\text { XI and XII so as to find the degree of alignment. The quantitative } \\
\text { analysis was done by using Surveys of Enacted Curriculum (SEC) } \\
\text { method. In quantitative analysis the content of the textbook was } \\
\text { analyzed with respect to student learning outcomes [SLOs] given in the } \\
\text { curriculum. It was found that content in the Education-XI and XII } \\
\text { textbook were not aligned to a desired level. Alignment Index (AI) of } \\
\text { Education XI and XII textbook were o.61 and o.5o respectively. This } \\
\text { misalignment was not same for all the categories of cognitive domain. } \\
\text { The outcomes of the study revealed that there were some gap between } \\
\text { curriculum and textbooks. The study lays great implications in the sense } \\
\text { that it provides feedback to curriculum developers and textbook writers } \\
\text { to consider alignment between curriculum objectives and textbook } \\
\text { content. The study suggests adequate training for the curriculum and } \\
\text { textbook developers to ensure alignment between national curriculum } \\
\text { and textbooks. }\end{array}$} \\
\hline ed 18 July 2020 & \\
\hline $\begin{array}{l}\text { Available Online } 30 \text { September } \\
2020\end{array}$ & \\
\hline Key & \\
\hline & \\
\hline Secon & \\
\hline JEL & \\
\hline I23, & \\
\hline ds.v6i & \\
\hline
\end{tabular}

(C) 2020 The authors. Published by SPCRD Global Publishing. This is an open access article under the Creative Commons Attribution-

NonCommercial 4.0

Corresponding author's email address: drnajam.ulkashif@iub.edu.pk

\section{Introduction}

Pakistan is a developing country and for making it develops and prospers, we need quality education, international standards meeting educational institutes and quality teachers. Curriculum is considered as a vehicle to transfer the societal values and norms through the teaching learning process in the educational institutions (Banks, 2015). Curriculum is a crux of education. Education is transfer of knowledge, attitudes and skills from one generation to the next, whereas curriculum "reflects forms of knowledge, habits of thinking, and cultural practices that a society considers important enough to pass on to succeeding generations" (Triche, 2002). Curriculum is revamping of child's experience to "the 


\section{Review of Economics and Development Studies, Vol. 6 (3) 2020, 687-702}

organized body of truth" (Dewey, 1902) and sum of "all the learning experiences planned and directed by the school" (Tylor, 1957). Curriculum is the product of mutual consensus among all the stakeholders such as curriculum specialists, educational managers, parents, students and teachers. It specifies the learning outcomes to be achieved after classroom instruction. It guides a teacher, educational manager, textbook/instructional material developer, and examiner. However, instructions given in curriculum are mostly not followed (Leithwood et al., 2004). Therefore, the curriculum specialists stress on curriculum alignment. They define curriculum alignment as the degree of coordination among curriculum, instructions, and assessment to facilitate students' learning (Martone \& Sireci, 2009). Curriculum alignment is the method of "educational quality control" where the "process of teaching and learning is predetermined, pre-paced, and pre-structured” (Rubin \& Kazanjian, 2011).

What societies envisage as important to learn constitutes the "official "or "intended "curriculum. What is delivered in the classroom constitutes the "implemented" or "enacted" curriculum. What students learn constitutes the "achieved" or "assessed" curriculum (Porter, 2002). Later, Roach, Niebling, and Kurz (2008) defined alignment "as the extent to which curricular expectations and assessments are in agreement and work together to provide guidance to educators' efforts to facilitate students' progress towards desired academic outcomes". The enacted curriculum provides an explanation for the presence or lack of presence of alignment between learner expectations and assessment (Anderson, 2002; Elliott et al, 2001; Pellegrino, 2006; Webb, 1997). The enacted curriculum represents collective and comprehensive output of all the educational stakeholders who have a role to play in any form for curriculum development. It represents the agreement after discussion of the educational experts, managers, and the teachers. However, it is vital for the teachers to plan their teaching in such a way that the objectives outlined in the intended curriculum are achieved (Kuhn \& Rundle, 2009).

Recently, the educationists have placed significant emphasis upon curriculum alignment (Porter, Smithson, Blank, \& Zeidner, 2007). Gagnon et al., 2009 proposed that the degree of co-relation among curriculum, instruction \& assessment is called as curriculum alignment. Teachers and learners are necessary pillars of instructions. These resources are necessary for the good alignment of curriculum. The written curriculum adopts shape when the agencies follow the standards to outline what content and procedures should be communicated in the schools. In theory, text-books are devised on the basis of written curriculum. The curriculum also guides the text-book evaluation. The term "Potentially implemented curriculum" to describe the role of te introduced. This role of textbooks made an intermediate stage between the written and the implemented curriculum. Increased attention is being paid to quality of textbooks across the globe (Tornroos, 2004). In Pakistan "Textbooks are considered as the sole and legitimate source of knowledge both for students and teachers". Given the importance of published curriculum materials in teaching and learning which is mainly in the form of textbooks in many developing countries including Pakistan, the establishment of an effective method of evaluation of these materials by their potential users and experts is an important goal. There are factors that make the textbook a quality textbook by ensuring the presence of those factors through adopting critical and rigorous evaluation processes (Bano, 2005). The arguments in favor of critical evaluation of textbooks and associated materials, but acknowledge that time, particularly in relation to textbook adoption, can be a challenge (Ladnier-Hicks., et al. 2010 and Jitendra et al., 2010). In Pakistan, curriculum formulation for higher secondary school level is the main responsibility of the Curriculum Wing, Ministry of Education. The Curriculum Wing develops and notifies curricula for all subjects from Early Childhood Education to higher secondary level (Grade XII) by involving subject and pedagogical experts from all provinces and other administrative parts of the country. Curriculum Wing is empowered through the Federal Supervision of Curricula, Textbooks and Maintenance of Standards of Education 


\section{Review of Economics and Development Studies, Vol. 6 (3) 2020, 687-702}

Act, 1976 to supervise curricula, textbooks and other learning materials as well as to maintain standards of education in the country (Government of Pakistan, 1976). All textbooks those are recommended for use in public sector institutes of the country should have been approved after their careful evaluation by Curriculum Wing. Therefore, it is usually recognized in educational fields in Pakistan that there are some deficiencies seen in textbooks, approved by Curriculum Wing and also in textbooks. These deficiencies have been reported with respect to different characteristics of quality textbooks including, but not limited to, content coverage, scope of developing understanding, horizontal and vertical alignment in the text, and approaches to the delivery of textbooks (Mahmood, 2006 and Tasneem, 2008). Textbook deficiencies have provoked much debate about the procedures used to gain textbook approval from CW and the textbooks themselves. Although there are many factors to account for deficiencies in the textbook selection procedures being used, two appear prominent: a) appropriate criteria against which to judge textbook characteristics; and b) the factors through which to identify the textbook characteristics to be judge against the curriculum criteria. By overcoming these deficiencies the quality of textbooks could be improved (Mahmood, 2011). The alignment of textbooks with the curriculum ensures alignment of instruction, assessment and evaluation with the curriculum. However, development of text-books aligned with the curriculum is considered one of the initial aspects for implementing of curriculum ( $\mathrm{Hu}$ et al., 2014). The curriculum document is considered to be the road map for the attainment of the national goals. For this purpose, the textbooks are developed in such a way that the contents presented in the textbooks are aligned with curriculum document. If there is no alignment in the textbooks and curriculum document, it is tough to achieve the desired objectives. Therefore, Bernard et al., (2014) adduced that researches do not validate the publishers' claim for devising text-books with reference to curriculum. Resultantly, textbooks in the Punjab-Pakistan can't be certainly aligned with the curriculum. In 2004, Human Development Foundation declared that textbooks in all over Pakistan have language, presentation issues as well as diverge from the national curriculum. In addition to this, misaligned text-books with curriculum have circulated in Punjab (Rassool et al., 2007). Mahmood (2011) examined the standard of prevailing text-books with internationally accepted yardstick. He concluded that it might be due to the least approach of the teachers to the National Curriculum, in Pakistan.

PCTB has developed quality standard for developing textbooks. The first standard to establish a quality text-book is the knowledge and awareness of the writer about curriculum of the specific subject (Punjab Textbook Board, 2014). It shows that compatibility level of textbooks to the curriculum is important yardstick for assessment of textbook. Doyle and Rosemartin (2012) explained that curriculum was misaligned where curriculum developers and implementers were not compatible. It is also revealed from different researches. Mahmood (2011) found that the textbooks were incompatible to the curriculum with reference to the 'Basic Components of Curriculum'. Furthermore, also observed that textbook developers in Pakistan were not familiar with the curriculum. Nayyar (2013) also unfolded that in Pakistan, textbooks are actually 'misinterpretation or misrepresentation' of the prevailing curriculum.

Analysis of studies conducted on textbooks in Punjab shows that (a) quality of textbooks has been examined independently, (b) few studies have analyzed textbook in relation to the curriculum and even these studies have not employed the recent alignment measurement methods, and (c) textbook content may not be compatible to the content suggested in the present curriculum. Previous research identifies that there was little alignment between the curriculum contents and textbooks (Sqires, 2005). Because of the inclination of the understanding that the deficiency of the alignment between the curriculum document and the textbooks is one basic reason for the letdown of students that eventually cause for the higher dropout rate (Brown \& Niemi, 2007). Additionally, the alignment of text-books to 


\section{Review of Economics and Development Studies, Vol. 6 (3) 2020, 687-702}

the prevailing curriculum is in line with the Curriculum Implementation Frame-work Punjab' developed by Punjab Curriculum and Textbook Board (2014). However, gap in literature exists about the studies giving the degree of alignment of the Education textbooks content to the content in National Curricula of Pakistan. The current study was carried out for probing that how much the content of Education Textbooks at Higher Secondary Level are compatible or aligned to the curriculum by applying the recent mechanism for the measurement of curriculum alignment. To recognize the significance of this area of research, some researchers have been done in Pakistan as well (Mahmood, Iqbal and Saeed, 20o9; Mahmood, 2011 and Shah, 2012), but focus of all these researches was the elementary school subjects. To identify alignment between curriculum and textbooks, no sufficient research has been met at higher secondary level for the Education subject in Punjab.

The subject Education is offered at secondary and Higher school level to the students of humanities group. The basic aim to offer this subject at higher secondary level is to prepare the students for the future teachers with basic or fundamental needs and objectives. Now, how much this aim is achieved with the offered curriculum through textbooks is the basic aim of the study. So the study based on investigation that to what extent is the content of Education Textbooks at Higher Secondary Level aligned with National Curriculum of Pakistan?

\section{Research Design}

The study was quantitative in nature. For quantitative analysis Surveys of Enacted Curriculum [SEC] method was used. This method has been used across the globe, particularly in United States of America, for measuring the level of alignment instruction and instructional materials with curriculum, [Studies conducted by (a) Liu, Zhang, Liang, Fulmer, Kim, \& Yuan, (2009) in China, USA \& Singapore, (b) Ndlovu \& Mji (2012) in South Africa, and (c) Bhatti, Jumani, \& Bilal (2015) in Pakistan, (d) Kurz, Elliott, Wehby, \& Smithson (2010) in USA]. The (SEC) model was developed by Andrew Porter and John Smithson from Wisconsin Center for Education Research. An important quality of SEC method for measurement of curriculum alignment is that it can be used for measurement of degree of alignment between content in textbooks with the objectives and content of curriculum. Therefore, SEC method of curriculum alignment was employed to find out quantitative measurement of alignment of content in Education Textbooks at Higher Secondary Level with that of curriculum. For this, SEC protocol was developed for curriculum and the textbooks.

The researcher analyzed the curriculum and then the textbooks. The contents given in the textbooks were analyzed. The basis of analysis was the number and nature of Students Learning Outcomes [SLOs]. Although SLOs were given in the curriculum for every chapter. The number and nature of SLOs were analyzed at chapter level. The research instrument (SEC protocol) for Education Textbook grade-XI was consisted of eight rows for the eight chapters and six columns for the six categories of cognitive domain (Remember, Understand, Apply, Analyze, Evaluate, and Create). In this way a matrix of $8 \times 6$ ( 48 cells) was obtained for the curriculum. The same 8X6 matrix (48 cells) was obtained for the Textbook grade-XI and 5X6 matrix (30 cells) for the curriculum and Textbook gradeXII. Then value in each cell was divided by the sum of values for every column. Then ratio difference was found by subtracting the values of every cell of one matrix (for curriculum) from the corresponding cell of the other matrix (for textbook). Quantitative measure of alignment was calculated by using Porter's (2002) formula of alignment index. Moreover, to calculate the strength of alignment, Fulmer's (2011) table of critical values was employed. This made possible to compare and contrast quantitatively the content in Textbooks with that of curriculum. Quantitative analysis was done through following documents: 
- National Curriculum of Education for Grade XI-XII , Ministry of Education (Curriculum Wing) Government of Pakistan, Islamabad.

- Textbook for Grade- XI published by Punjab Curriculum and Textbook Board, Lahore.

- Textbook for Grade- XII published by Punjab Curriculum and Textbook Board, Lahore.

\section{Results}

Table 1 exhibits alignment of Education-XI Textbook with curriculum. It is clear from the table that alignment index value is 0.61 which indicates that Education-XI Textbook is considerable misaligned with the curriculum. The content in the textbook is also misaligned individually with respect to all categories of cognitive domain. Individually the calculated AI values for Remember, Understand, Apply, Analyze, Evaluate and Create categories of cognitive domain are o.86, o.80, 0.50, 0.50, 0.50 and 0.50 , respectively. The misalignment is not same relating to different levels of cognitive domain. The content in textbook for the remember category is significant aligned ( $\mathrm{AI}=0.86)$ and for understand category is considerable aligned $(\mathrm{AI}=0.80)$ with the curriculum. The content in textbook for the Apply, Analyze, Evaluate and Create categories is critically misaligned (AI=0.50) with the curriculum. Following results revealed from the quantitative analysis of data.

Table 1: Alignment of Education Grade-XI Textbook with Curriculum

\begin{tabular}{|c|c|c|c|c|c|c|}
\hline \multicolumn{7}{|c|}{ Ratio Difference of SLOs with respect to } \\
\hline Chapter Nos & Remember & Understand & Apply & Analyze & Evaluate & Create \\
\hline $\mathbf{1}$ & 0.08 & 0.05 & 0.11 & 0.18 & 0.08 & 0.00 \\
\hline $\mathbf{2}$ & 0.01 & 0.03 & 0.05 & 0.18 & 0.08 & 0.00 \\
\hline $\mathbf{3}$ & 0.01 & 0.09 & 0.05 & 0.27 & 0.25 & 0.00 \\
\hline $\mathbf{4}$ & 0.09 & 0.01 & 0.84 & 0.00 & 0.29 & 0.00 \\
\hline $\mathbf{5}$ & 0.03 & 0.01 & 0.00 & 0.00 & 0.08 & 0.00 \\
\hline $\mathbf{6}$ & 0.01 & 0.07 & 0.16 & 0.00 & 0.04 & 0.00 \\
\hline $\mathbf{7}$ & 0.04 & 0.13 & 0.11 & 0.00 & 0.12 & 0.00 \\
\hline $\mathbf{8}$ & 0.01 & 0.01 & 0.33 & 0.36 & 0.04 & 1.00 \\
\hline TOTAL & 0.28 & 0.40 & 1.00 & 1.00 & 0.98 & 1.00 \\
\hline Alignment Index & 0.86 & 0.80 & 0.50 & 0.50 & 0.50 & 0.50 \\
\hline Average Alignment Index (AI) $\mathbf{0 . 6 1}$ & & & & \\
\hline
\end{tabular}

Figure 1 indicates comparison of content in Education-XI textbook with curriculum relating to remember level of cognitive domain. It is obvious from the graph that except chapter 6 and 7 , the textbook provides more content about learning outcomes relating to remember level with that in curriculum.

Figure 1: Alignment between content in textbook and curriculum: Remember level

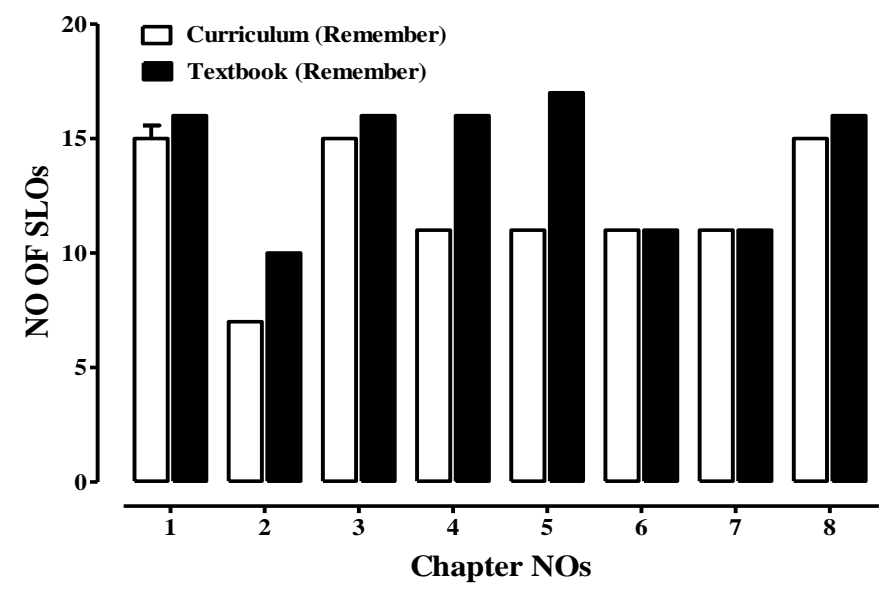


Figure 2: Alignment between content in textbook and curriculum: Understand Level

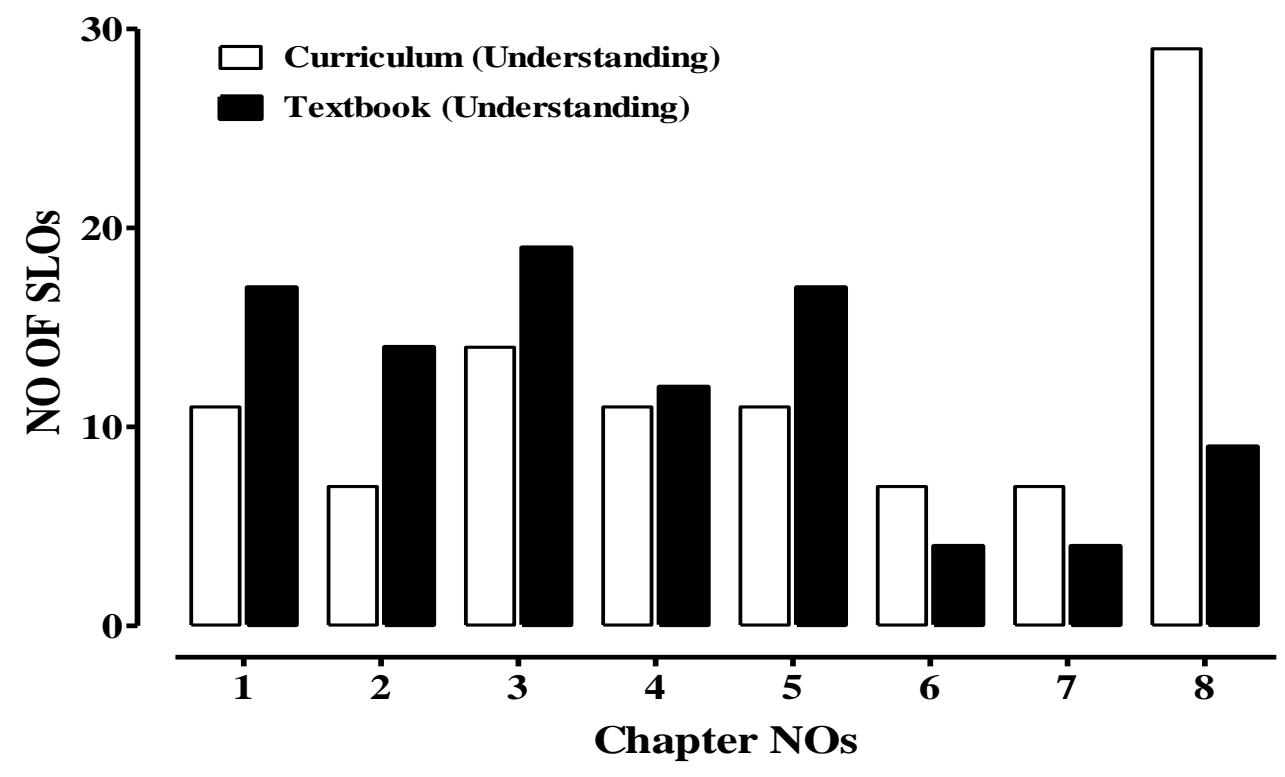

Figure 2 indicates comparison of content in Education-XI textbook with curriculum relating to understand level of cognitive domain. It is obvious from the graph that in chapter 1, 2, 3, 4 and 5 the textbook provides more content about learning outcomes relating to understand level with that in curriculum. In chapter 6,7 and 8 curriculum provides more content about learning outcomes relating to understand level with respect to textbook.

Figure 3 exhibits comparison of content in Education-XI textbook with curriculum relating to apply level of cognitive domain. It is obvious from the graph that in chapter 1, 2, 3, 4 6, 7 and 8 the curriculum provides more content about learning outcomes relating to apply level as compared to textbook. In chapter 5 curriculum and textbook provide no content about learning outcomes relating to apply level.

Figure 3: Alignment between content in textbook and curriculum: Apply level

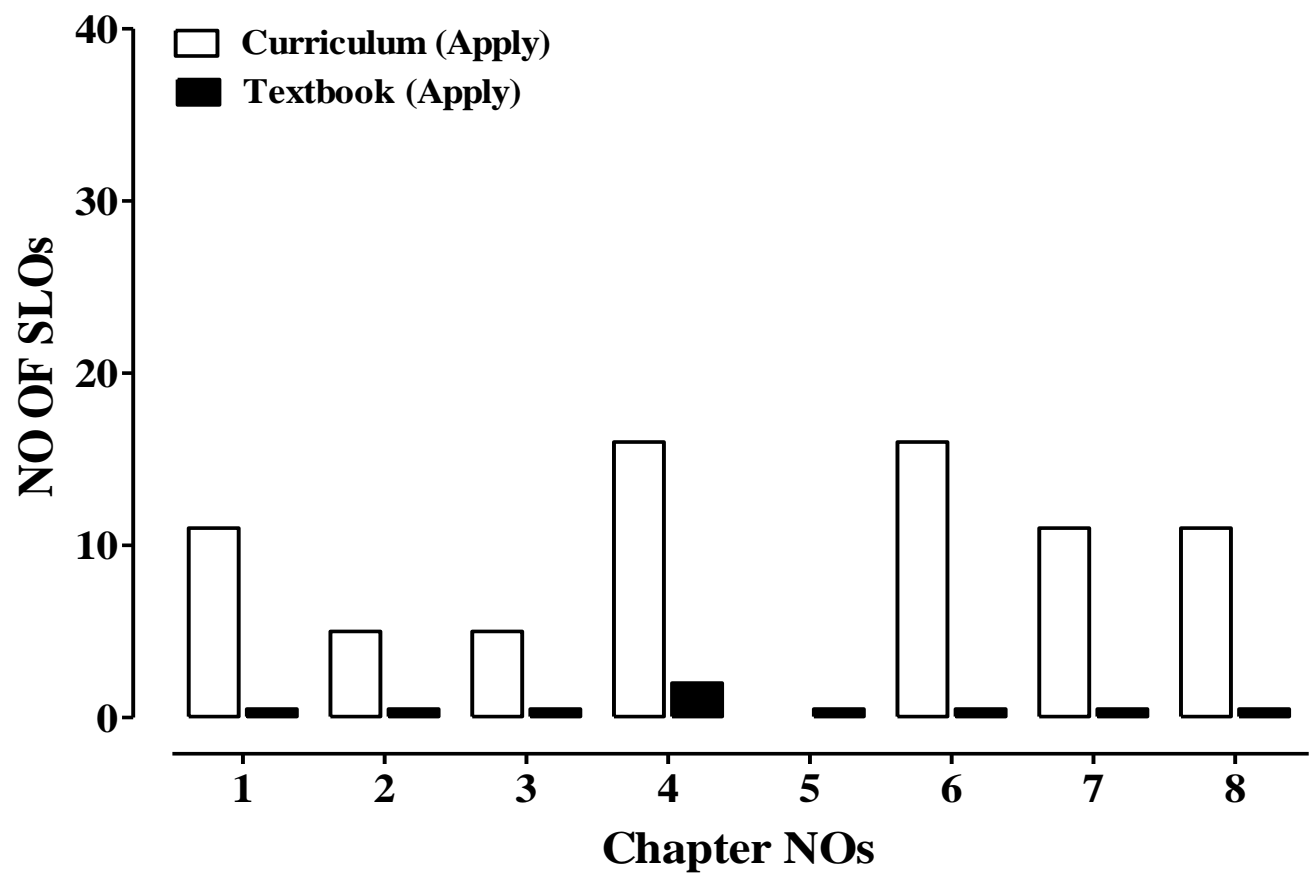


Figure 4: Alignment between content in textbook and curriculum: Analyze Level

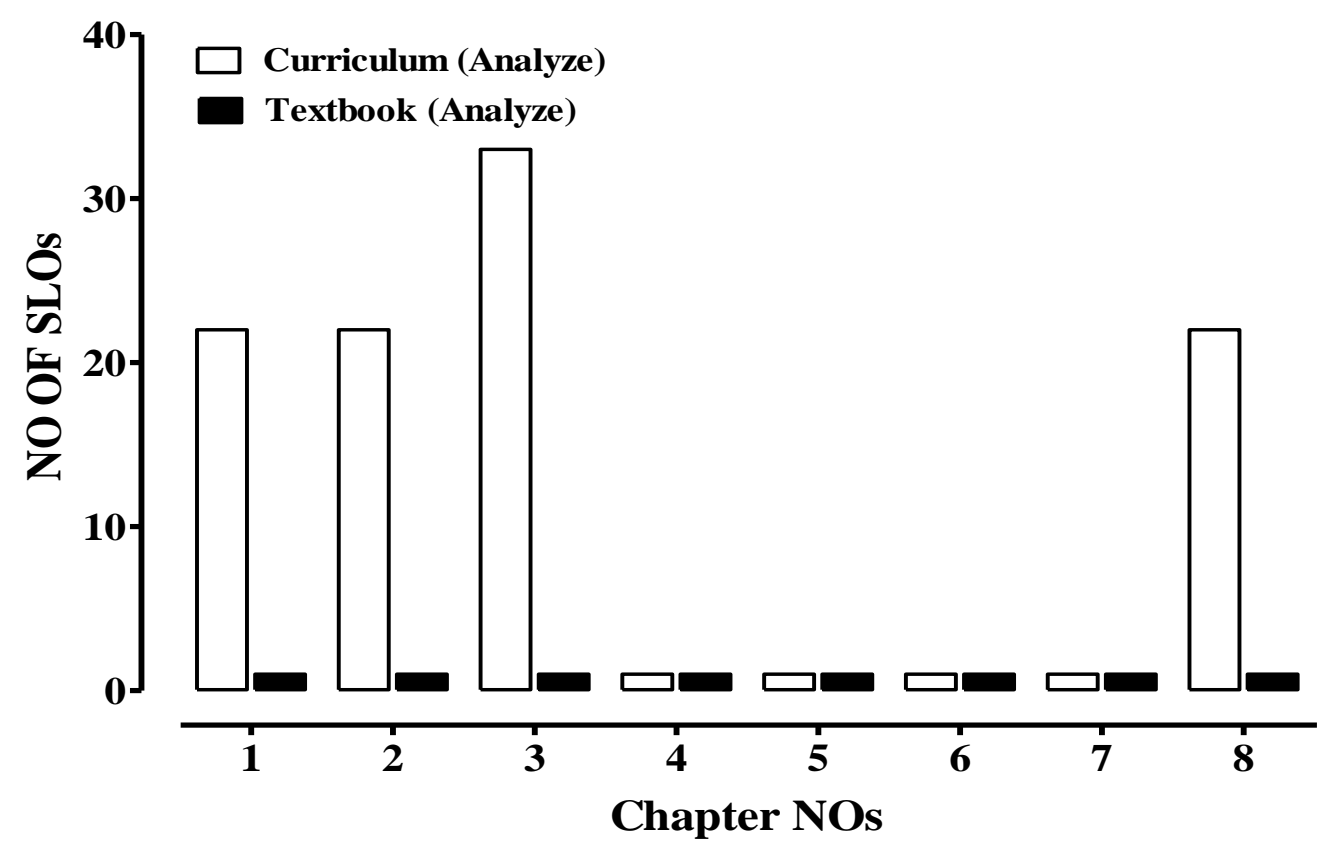

Figure 4 indicates comparison of content in Education-XI textbook with curriculum relating to analyze level of cognitive domain. It is evident from the graph that the textbook provides no content about learning outcomes relating to analyze level of cognitive domain as opposed to the curriculum which suggests learning outcomes in chapter $1,2,3$ and 8.

Figure 5 indicates comparison of content in Education-XI textbook with curriculum relating to evaluate level of cognitive domain. It is evident from the graph that the textbook provides no content about learning outcomes relating to evaluate level of cognitive domain as opposed to the curriculum which suggests learning outcomes in chapter 1, 2, 3, 4, 5 and 6.

Figure 5: Alignment between content in textbook and curriculum: Evaluate Level

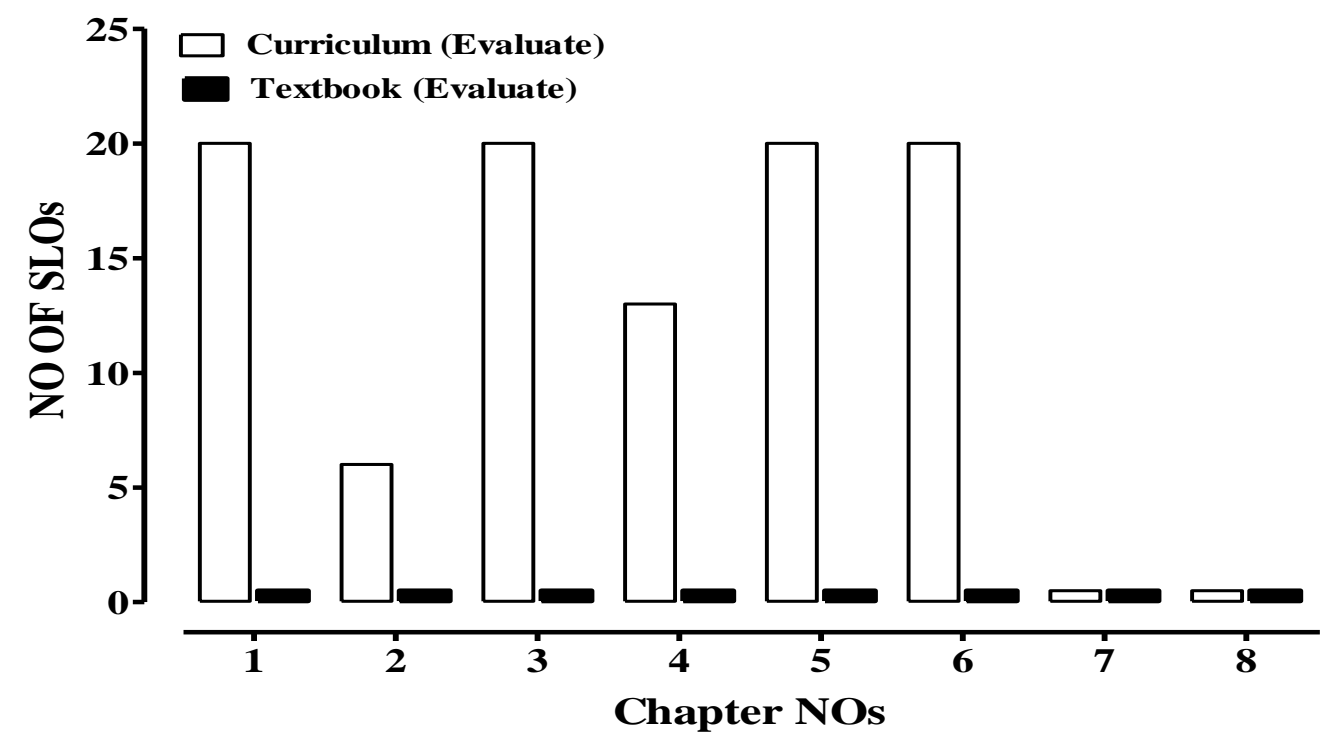

Figure 6 indicates comparison of content in Education-XI textbook with curriculum relating to create level of cognitive domain. It is evident from the graph that the textbook provides no content about learning outcomes relating to create level of cognitive domain as opposed to the curriculum 
which suggests learning outcomes in chapter 6 and 8.

Figure 6: Alignment between content in textbook and curriculum: Create Level

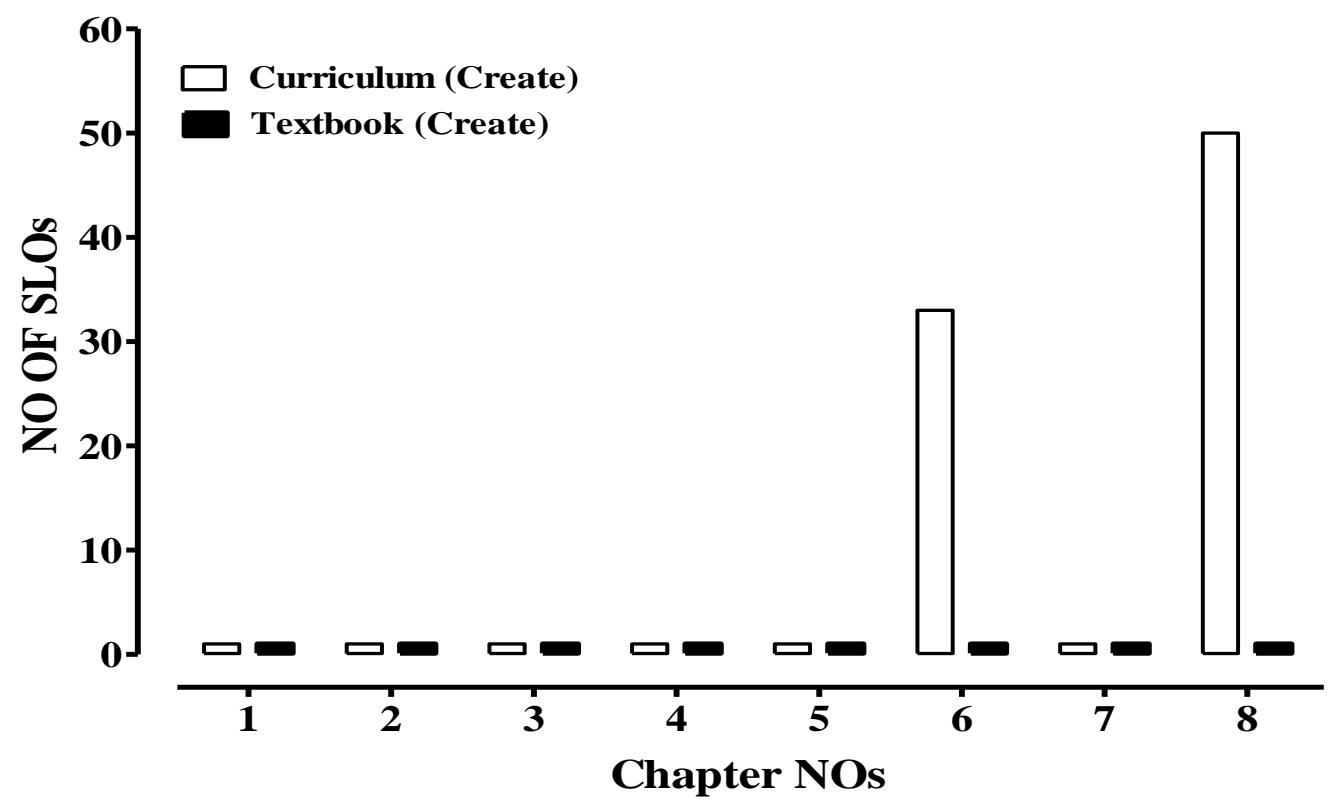

Table 2 exhibits alignment of Education-XII Textbook with curriculum. It is clear from the table that alignment index value is 0.50 which indicates that Education-XII Textbook is not aligned with the curriculum. The content in the textbook is also misaligned individually with respect to all categories of cognitive domain. Individually the calculated AI values for Remember, Understand, Apply, Analyze, Evaluate and Create categories of cognitive domain are 0.50, 0.50, 0.50, 0.50, 0.50 and 0.50 , respectively. The misalignment is same relating to different levels of cognitive domain. The content in textbook is critically misaligned $(\mathrm{AI}=0.50)$ with the curriculum.

Table 2: Alignment of Education Grade-XII Textbook with Curriculum

\begin{tabular}{|c|c|c|c|c|c|c|}
\hline \multicolumn{7}{|c|}{ Ratio Difference of SLOs with respect to } \\
\hline Chapter NOs & Remember & Understanding & Apply & Analyze & Evaluate & Create \\
\hline $\mathbf{1}$ & 0.24 & 0.29 & 0.20 & 0.00 & 0.13 & 0.00 \\
\hline $\mathbf{2}$ & 0.14 & 0.14 & 0.13 & 0.12 & 0.13 & 0.00 \\
\hline $\mathbf{3}$ & 0.20 & 0.14 & 0.20 & 0.37 & 0.20 & 1.00 \\
\hline $\mathbf{4}$ & 0.19 & 0.21 & 0.20 & 0.00 & 0.13 & 0.00 \\
\hline $\mathbf{5}$ & 0.33 & 0.22 & 0.47 & 0.51 & 0.41 & 0.00 \\
\hline TOTAL & 1.00 & 1.00 & 1.00 & 1.00 & 1.00 & 1.00 \\
\hline Alignment Index & 0.50 & 0.50 & 0.50 & 0.50 & 0.50 & 0.50 \\
\hline \multicolumn{7}{|l|}{ Average Alignment Index $=0.50$} \\
\hline
\end{tabular}


Figure 7: Alignment between content in textbook and curriculum: Remember level

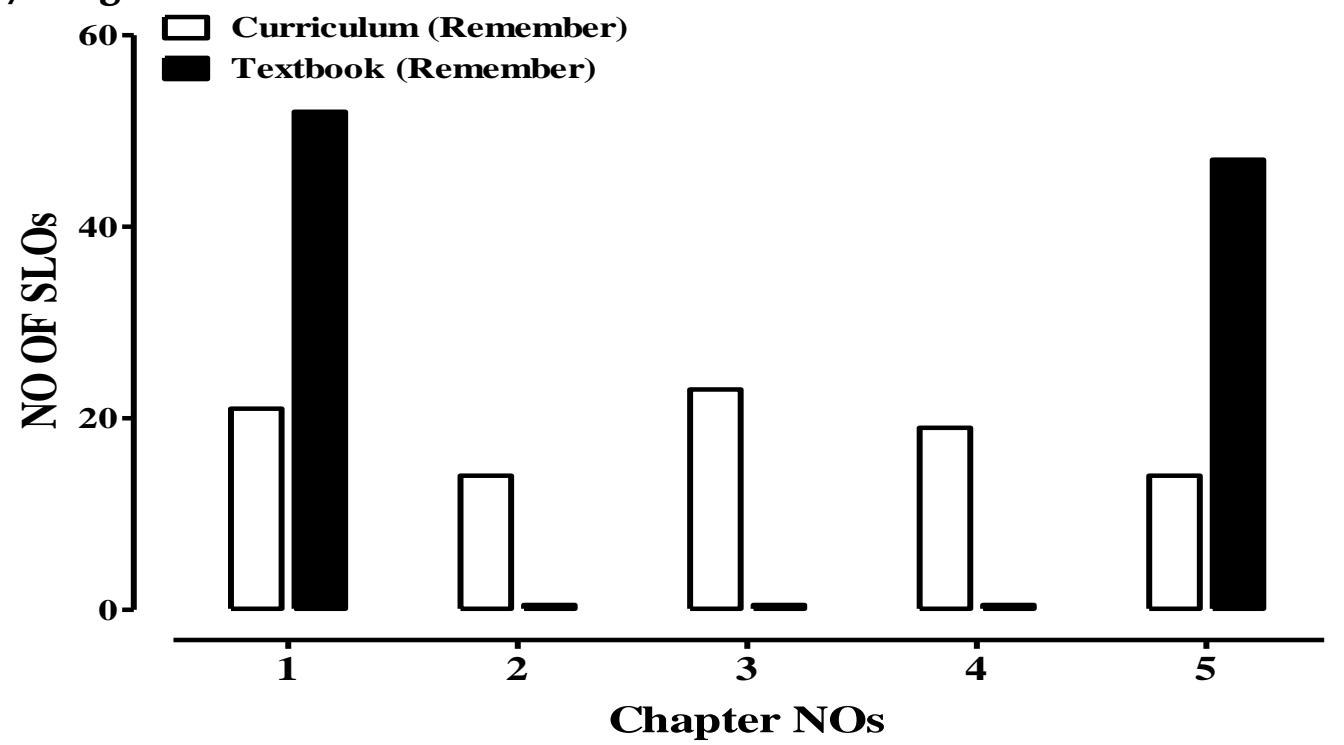

Figure 7 indicates comparison of content in Education-XII textbook with curriculum relating to remember level of cognitive domain. It is obvious from the graph that except chapter 1 and 5 , the textbook provides no content about learning outcomes relating to remember level with that in curriculum.

Figure 8: Alignment between content in textbook and curriculum: Understand Level

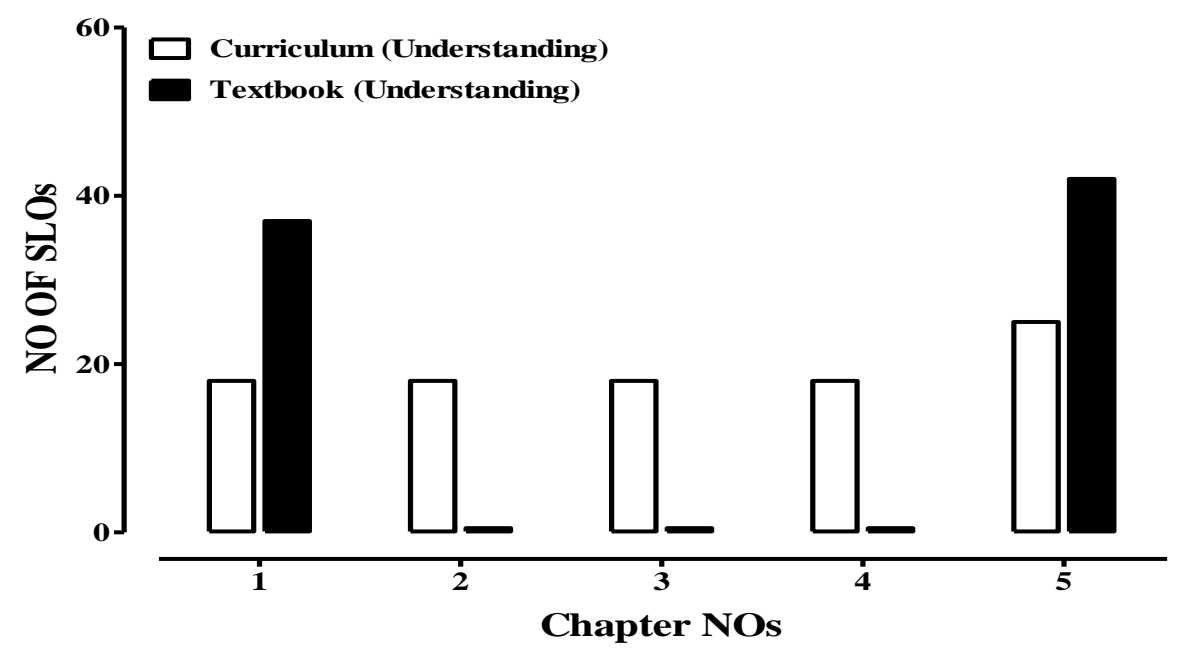

Figure 8 indicates comparison of content in Education-XII textbook with curriculum relating to understand level of cognitive domain. It is obvious from the graph that except chapter 1 and 5 the textbook provides no content about learning outcomes relating to understand level with that in curriculum. 
Figure 9: Alignment between content in textbook and curriculum: Apply level

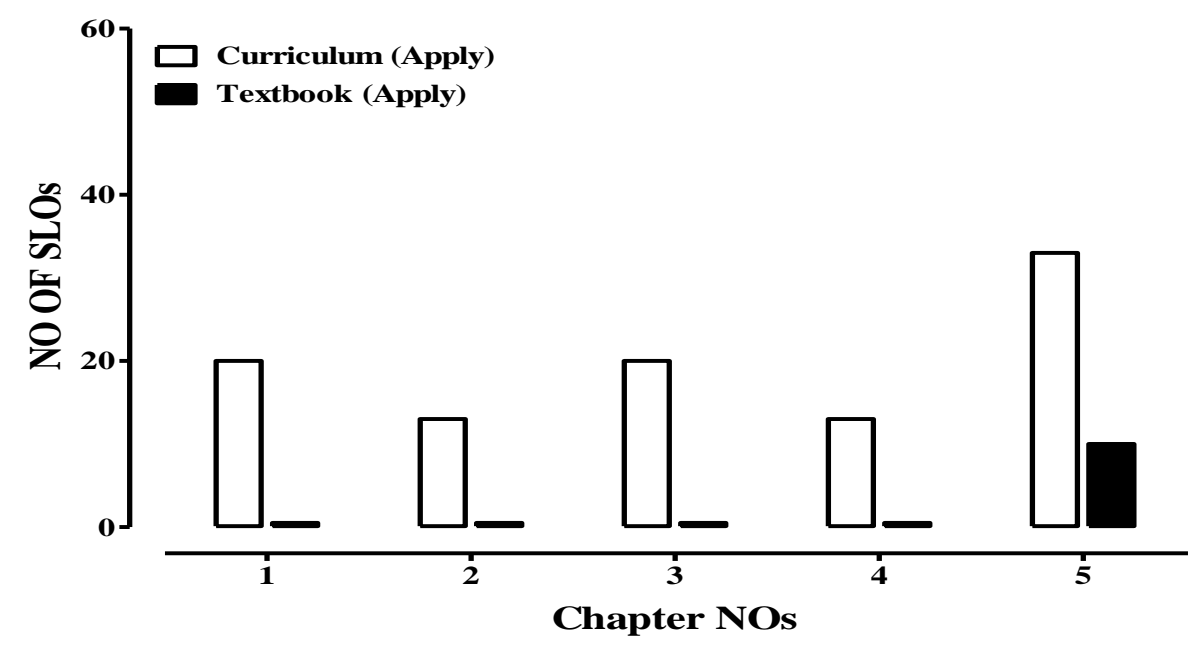

Figure 9 exhibits comparison of content in Education-XII textbook with curriculum relating to apply level of cognitive domain. It is obvious from the graph that except chapter 5 the textbook provides no content about learning outcomes relating to apply level as compared to curriculum.

Figure 10 indicates comparison of content in Education-XII textbook with curriculum relating to analyze level of cognitive domain. It is evident from the graph that the textbook provides no content about learning outcomes relating to analyze level of cognitive domain as opposed to the curriculum which suggests learning outcomes in chapters 2,3 and 5.

Figure 10: Alignment between content in textbook and curriculum: Analyze Level

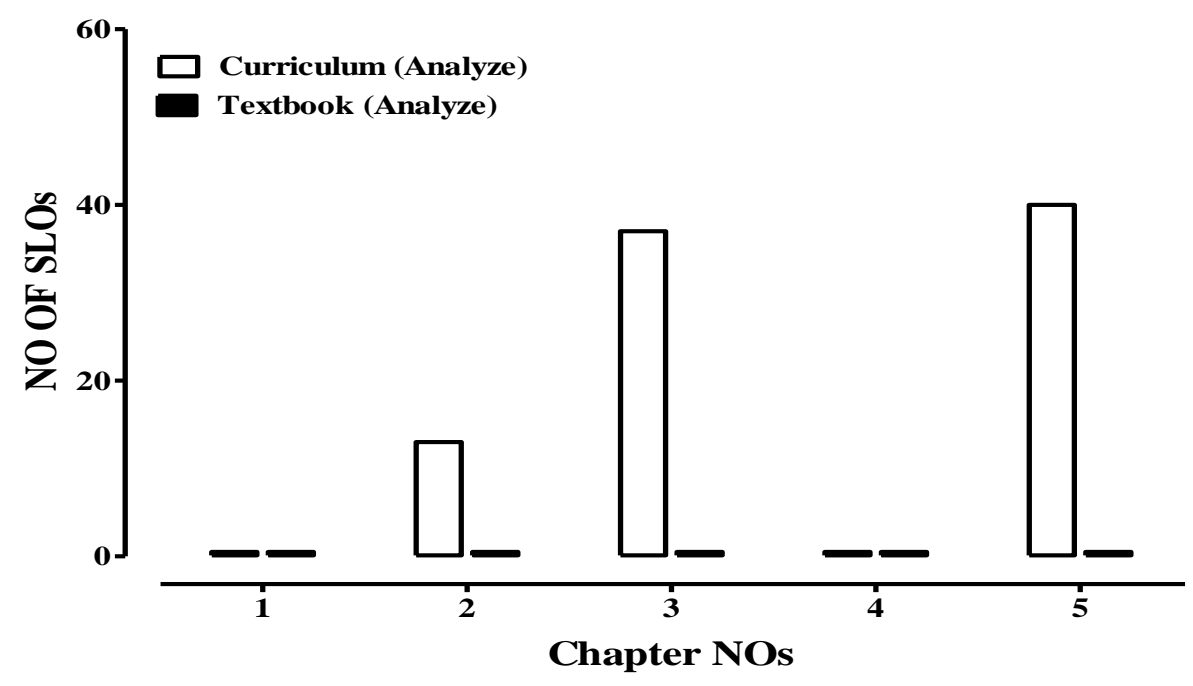

Figure 11 indicates comparison of content in Education-XII textbook with curriculum relating to evaluate level of cognitive domain. It is evident from the graph that the textbook provides no content about learning outcomes relating to evaluate level of cognitive domain as opposed to the curriculum which suggests learning outcomes in chapter $1,2,3,4$, and 5 . 


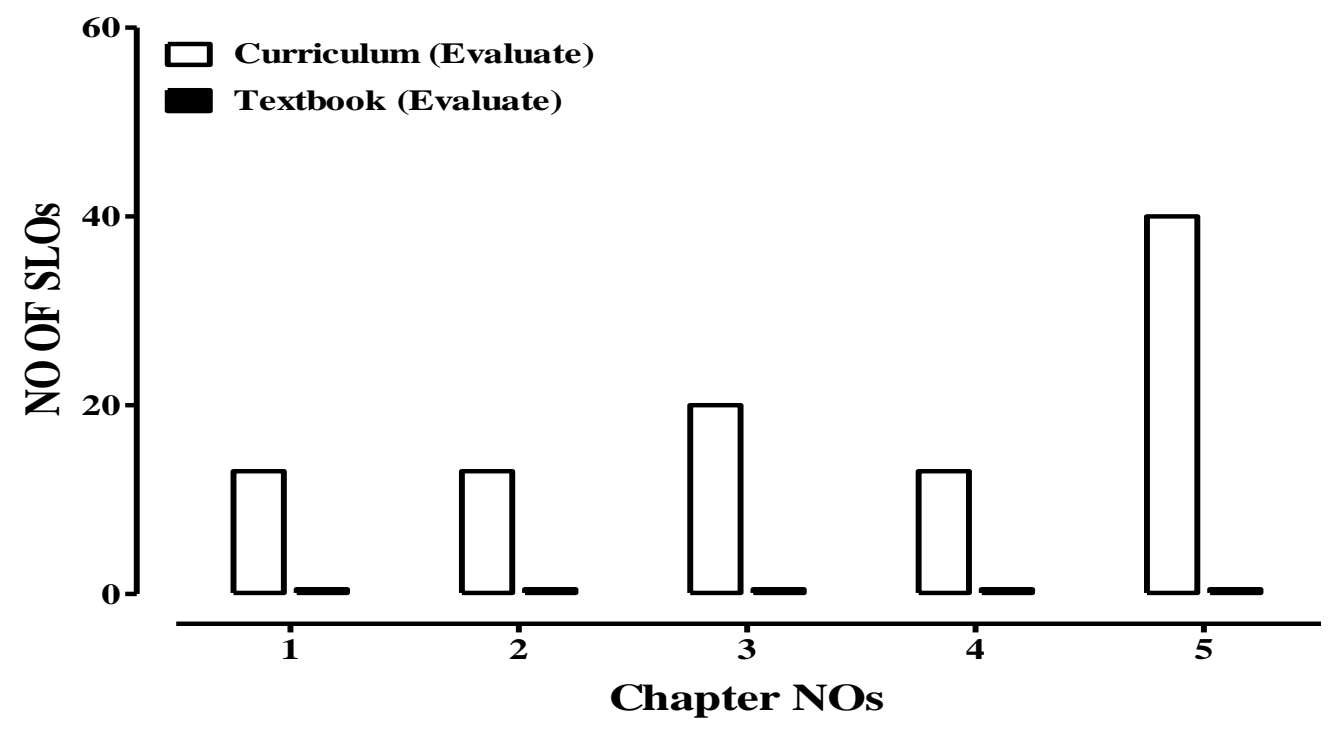

Figure 12: Alignment between content in Textbook and curriculum: Create Level

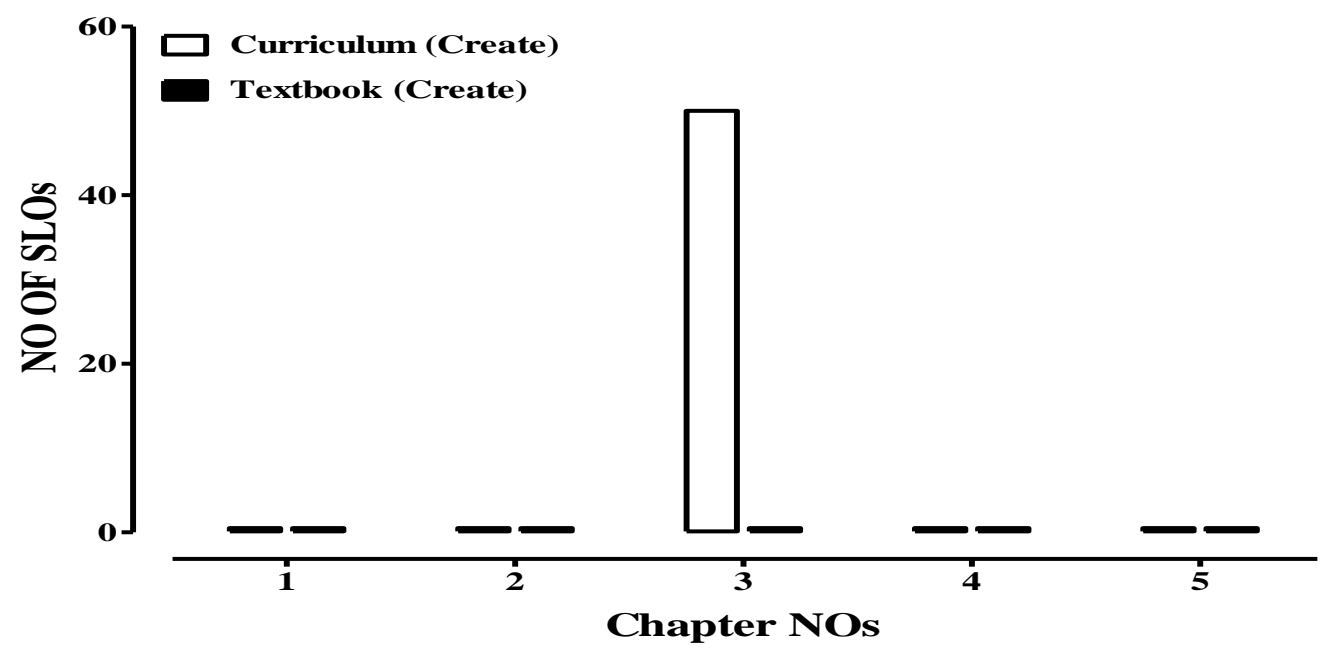

Figure 12 indicates comparison of content in Education-XII textbook with curriculum relating to create level of cognitive domain. It is evident from the graph that the textbook provides no content about learning outcomes relating to create level of cognitive domain as opposed to the curriculum which suggests learning outcomes in chapter 3 only.

\section{Discussion}

On the basis of quantitative analysis, the findings are as, after completing the content analysis of the textbooks with respect to the SLOs proposed in the curriculum, the degree of alignment was found. The textbooks are not aligned with curriculum document. The degree of textbooks alignment fluctuates and there is an inverse relationship between textbook and curriculum alignment. Textbooks are not written specifically to align with learning standards, so given in the curriculum document. The main objectives were proposed in the light of curriculum document used by the curriculum development agency (Ministry of Education, Curriculum Wing, Islamabad). The main aim of introducing Education as a subject at Higher Secondary level was an innovative way to increase the number of teachers but the 


\section{Review of Economics and Development Studies, Vol. 6 (3) 2020, 687-702}

curriculum was not designed to meet this need (National Curriculum of Education, 2011). Some content relating to professional skills was included in the curriculum but textbooks were not developed to achieve the desired objectives. There were three main standards given in the said curriculum document; a) knowledge; b) skills; c) dispositions. As for as knowledge standard is concerned, textbooks are overloaded but skill standard is completely ignored. The textbooks are not designed to develop professional skills in students. The alignment between the curriculum objectives and the Textbooks was ignored. The content in the Education Grade-XI and XII Textbooks was misaligned with the curriculum. Alignment Index (AI) of Education Grade- XI and XII textbooks were o.61 and 0.50 respectively

It was found that alignment index value 0.61 indicates that Education Grade-XI Textbook was considerably misaligned with the curriculum. The content in the textbook was also misaligned individually with respect to all categories of cognitive domain. Individually the calculated AI values for Remember, Understand, Apply, Analyze, Evaluate and Create categories of cognitive domain were o.86, $0.80,0.50,0.50,0.50$ and 0.50 , respectively. The misalignment was not same relating to different levels of cognitive demand. The content in the textbook for the remember category was significant aligned $(\mathrm{AI}=0.86)$ and for understand category was considerable aligned $(\mathrm{AI}=0.80)$ with the curriculum. The content in textbook for the Apply, Analyze, Evaluate and Create categories was critically misaligned ( $\mathrm{AI}=0.50$ ) with the curriculum. However, it was concluded that the textbook failed to provide the content with respect to higher order of cognitive demand viz. Apply, Analyze, Evaluate and Create. It was also found that content in the textbook Grade-XI was unable to achieve the main aim of curriculum, which was due to over emphasis on Remember level and neglecting the skills.

The analysis of Education Grade-XII Textbook revealed misalignment with curriculum. It was concluded that alignment index value was 0.50 that was critically misaligned with the curriculum. Individually the calculated AI values for Remember, Understand, Apply, Analyze, Evaluate and Create categories of cognitive domain was 0.50. The misalignment was same relating to different levels of cognitive domain. The content in textbook was critically misaligned ( $\mathrm{AI}=0.50)$ with the curriculum. It was concluded that Education textbook Grade -XII was unable to develop the desired professional skills in students.

Previous researches (Akhtar (2004), Rehman (2004) and Faize (2011) showed that the textbooks in Pakistan consisted of irrelevant content which could not ensure realization of outcomes proposed in the curriculum. Present research showed that the Education textbooks Grade-XI and XII were overloaded with respect to only Remember level of cognitive domain. The higher levels of cognitive domain may ignored completely. Mostly teachers and students consider that textbooks are genuine and authentic source of knowledge (Jong et al., 2005). Government of Pakistan (2006) acknowledges that at present, the text-books are unique and exclusive source for teachers and learners in Pakistan. Mahmood (2011), revealed that textbooks in Pakistan do not fulfill the globally accepted quality standard of textbook.

For harmonizing the content in the Education textbooks Grade-XI and XII with the curriculum, it is necessary that emphasis of content may be changed from lower level to higher level. There should be less content related to remember category of cognitive domain. More content is needed for Understand category of cognitive domain. In the curriculum, there are a few SLOs with respect to higher order of cognitive domain viz. Apply, Analyze, Evaluate and Create. However, these SLOs are very significant and content should be provided in the textbook to achieve these SLOs. It shows that textbooks do not treat topics deeply contrary to demand of curriculum. Curriculum suggests achieving higher order 


\section{Review of Economics and Development Studies, Vol. 6 (3) 2020, 687-702}

learning outcomes for some topics, but textbook content is limited to lower order learning outcomes of knowledge category and to some comprehension category. The main objective of the curriculum was to develop teaching skills in students but textbooks are failed to provide content to achieve the objectives. However, a gap was found in the textbooks for providing any activity for the development of skills like teaching skills, critical thinking, problem solving, creativity and productivity in higher secondary school students.

The gap between the textbooks and the curriculum reflects lack of coordination between curriculum developers and the textbook writers. Textbook writers should follow the guidelines for developing textbooks as prescribed in the national curriculum. Proper mechanism should be adopted to devise and publish textbooks so that the content in the textbooks is genuine, authentic, flawless and critically aligned with the proposed objectives in the curriculum. There should be at least one common person in the development of curriculum and writing textbook to enhance the alignment between curriculum and the textbook.

Curriculum alignment can provide a framework for examining the extent to which the learner expectations, instructions and assessments were aligned. The findings of this study contribute towards improving the learning of students with its call to explicitly identify cognitive processes at all levels to be learned, and to determine if the enacted curriculum and the assessed curriculum, both revised to take account of the cognitive processes, are properly aligned.

\section{Conclusions and Recommendations}

Keeping in view the results and discussions, it was concluded that the textbooks of Education for higher secondary level do not meet the criteria necessary for skills development among higher secondary school students in present era. The outcomes of the study revealed that there were some gap between objectives of curriculum and textbooks. The study suggests adequate training for the curriculum and textbook developers to ensure alignment between national curriculum and textbooks. When a new curriculum is put together or when a major revision is done at any level, several learning trajectories need to be incorporated in the curriculum. It is essential to discuss the learning trajectory that leads to the expected outcomes.

National Curriculum of Education should aim at encouraging students to: (a) develop a sense for teaching profession, (b) use of technology to acquire new knowledge and (c) engage in research related activities appropriate to their interests and abilities. Textbook content should congruent with the curriculum with respect to accuracy of content and being related to the aims of curriculum. However, the textbook writers should follow the guidelines given in the curriculum.

Since teachers in public sector in Pakistan have almost no access to the national curriculum document, provided only to textbook writers for their guidance (Bano, 2005), it is imperative that the textbook writers have an additional responsibility to ensure that the textbook reflects all the objectives of curriculum and all characteristics proposed in the curriculum document. In order to meet this requirement and overcome above mentioned deficiencies, it is recommended that $\mathrm{CW}$ must devise explicit criteria that content in textbook do not deviate from the objectives of the curriculum. A well planned Education curriculum is needed to achieve the desired objectives. If the students are provided with an organized and systematic curriculum then they can excel in professional field. Teachers should also be included in the pool to identify issues related to the effectiveness and make necessary changes in the curriculum. Teachers of the respective level of textbook must be part of textbook writer's team. Teaching Education at higher secondary level should support beginner students, master the essential 


\section{Review of Economics and Development Studies, Vol. 6 (3) 2020, 687-702}

principles of understanding teaching methodology, teaching strategies.

\section{References}

Akhtar, M. (2004). Analysis of curriculum process and development of a model for secondary level in Pakistan (Unpublished doctoral dissertation). University of Arid Agriculture Rawalpindi.

Anderson, L. W. (2002). Curricular alignment: A re-examination. Theory Into Practice, 41(4), 255-260. Banks, J. A. (2015). Cultural diversity and education: Foundations, curriculum, and teaching. Routledge. Bano, Y. (2005). Curriculum and Textbooks: Issues and Challenges in Pakistan. ANTRIEP Newsletter, 10 (1), 3-8.

Bernard, R. M., Borokhovski, E., Schmid, R. F., Tamim, R. M., \& Abrami, P. C. (2014). A meta-analysis of blended learning and technology use in higher education: From the general to the applied. Journal of Computing in Higher Education, 26(1), 87-122.

Bhatti, A. J., Jumani, N. B., \& Bilal, M. (2015). Analysis of Alignment between Curriculum and Biology Textbook at Secondary Level in Punjab. Pakistan Journal of Social Sciences (PJSS), 35(1).

Brown, R. S., \& Niemi, D. N. (2007). Investigating the Alignment of High School and Community College Assessments in California. National Center Report\# 07-3. National Center for Public Policy and Higher Education.

Dewey, J. (1902). "The child and the curriculum”. Chicago: University of Chicago Press.

Doyle, W., \& Rosemartin, D. (2012). The ecology of curriculum enactment: Frame and task narratives. In Interpersonal relationships in education (pp. 137-147). Brill Sense.

Elliott, S. N., Braden, J., P., \& White, J. (2001). Assessing one and all: Educational accountability for students with disabilities. Arlington, VA: Council of Exceptional Children.

Faize, F. A. (2011).Problems and prospects of science education at secondary level in Pakistan (Unpublished doctoral dissertation). Faculty of Social Sciences, International Islamic University, Islamabad.

Fulmer, G. W. (2011). Estimating critical values for strength of alignment among curriculum, assessments, and instruction. Journal of Educational and Behavioral Statistics, 36(3), 381-402.

Gagnon, J. C., Barber, B. R., Van Loan, C., \& Leone, P. E. (2009). Juvenile correctional schools: Characteristics and approaches to curriculum. Education and Treatment of Children, 673-696.

Government of Pakistan (1976). The Federal Supervision of Curricula, Textbooks and maintenance of Standards of Education Act 1976. Islamabad: Curriculum Wing, Ministry of Education

Government of Pakistan (2011). National curriculum of education, Islamabad: Curriculum Wing, Ministry of Education

Hu, Q., Li, F., \& Chen, C. F. (2014). A smart home test bed for undergraduate education to bridge the curriculum gap from traditional power systems to modernized smart grids. IEEE Transactions on Education, 58(1), 32-38.

Mahmood, k. (2006). The Process of Textbook Approval: A Critical Analysis. Bulletin of Education \& Research, 28(1), 1-21.

Mahmood, K. (2011). Conformity to quality characteristics of textbooks: The illusion of textbook evaluation in Pakistan. Journal of research and Reflections in Education, 5(2), 170-190.

Mahmood, K., Iqbal, M. Z., \& Saeed, M. (2009). Textbook evaluation through quality indicators: The case of Pakistan. Bulletin of Education and Research, 31(2), 1-27.

Ndlovu, M., \& Mji, A. (2012). Alignment between South African mathematics assessment standards and the TIMSS assessment frameworks. pythagoras, 33(3), 1-9.

Jitendra, A. K., Griffin, C. C., \& Xin, Y. P. (2010). An evaluation of the intended and implemented curricula's adherence to the NCTM standards on the mathematics achievement of third grade students: A case study. Journal of Curriculum and Instruction, 4(2), 33-50.

Kuhn, K. A. L., \& Rundle-Thiele, S. R. (2009). Curriculum Alignment: Exploring Student Perception of 


\section{Review of Economics and Development Studies, Vol. 6 (3) 2020, 687-702}

Learning Achievement Measures. International Journal of Teaching and Learning in Higher Education, 21(3), 351-361.

Kurz, A., Elliott, S. N., Wehby, J. H., \& Smithson, J. L. (2010). Alignment of the intended, planned, and enacted curriculum in general and special education and its relation to student achievement. The journal of special education, 44(3), 131-145.

Ladnier-Hicks, J., McNeese, R. M., \& Johnson, J. T. (2010). Third grade reading performance and teacher perceptions of the Scott Foresman Reading Street program in Title I schools in South Mobile County. Journal of Curriculum and Instruction, 4(2), 51-70. doi:10.3776/joci.2010.v4n2p51-70

Leithwood, K., Seashore, K., Anderson, S., \& Wahlstrom, K. (2004). Review of research: How leadership influences student learning.

Liu, X., Zhang, B., Liang, L. L., Fulmer, G., Kim, B., \& Yuan, H. (2009). Alignment between the physics content standard and the standardized test: A comparison among the United States-New York State, Singapore, and China-Jiangsu. Science Education, 93(5), 777-797.

Mahmood, K. (2011, December). Conformity to Quality Characteristics of Textbooks: The Illusion of Textbook Evaluation in Pakistan. (M.S. Mirza, Ed.) Journal of Research and Reflections in Education, 5(2), 170-190.

Martone, A., \& Sireci, S. G. (2009). Evaluating alignment between curriculum, assessment, and instruction. Review of educational research, 79(4), 1332-1361.

Nayyar, A. H. (2013). A missed opportunity: Continuing flaws in the new curriculum and textbooks after reforms. draft report prepared for Jinnah Institute, Islamabad.

Punjab Curriculum and Textbook Board. (2014). Curriculum implementation framework Punjab-2014. Lahore: Punjab Curriculum and Textbook Board.

Pellegrino, J. (2006). Rethinking and redesigning curriculum, instruction and assessment. Paper

Commissioned by the National Center on Education and the Economy for the New Commission on the Skills of the American Workforce. National Center on Education and the Economy.

Porter, A. C. (2002). Measuring the content of instruction: Uses in research and practice. Educational Researcher, 31(7), 3-14.

Porter, A. C., Smithson, J., Blank, R., \& Zeidner, T. (2007). Alignment as a teacher variable. Applied Measurement in Education, 20(1), 27-51.

Rassool, N., Heugh, K., \& Mansoor, S. (2007). Global issues in language, education and development: Perspectives from postcolonial countries (Vol. 4). Multilingual matters.

Rehman, F. (2004). Analysis of National science curriculum (chemistry) at secondary level in Pakistan. University of Arid Agriculture, Rawalpindi.

Roach, A. T., Niebling, B. C., \& Kurz, A. (2008). Evaluating the alignment among curriculum, instruction, and assessments: Implications and applications for research and practice. Psychology in the Schools, 45, 158-176.

Rubin, D., \& Kazanjian, C. (2011). "Just another brick in the wall": Standardization and the devaluing of education. Journal of Curriculum and Instruction, 5(2), 94-108.

Shah, R. (2012). Goodbye conflict, hello development? Curriculum reform in Timor-Leste. International Journal of Educational Development, 32(1), 31-38.

Squires, D. (2012). Curriculum alignment research suggests that alignment can improve student achievement. The Clearing House: A Journal of Educational Strategies, Issues and Ideas, 85(4), 129-135.

Tasneenm, F. (2008). Exploration of post-colonial English curriculum: an investigation of an under graduate English textbook in Pakistani University. Master's Thesis Unpublished, Faculty of Education, York University, Toronto, Ontario.

Tornroos, J. (2004). Mathematics textbooks, opportunity to learn and achievement, from http://www.icmeorganisers.dk/dg14/DG14-Jukka.pdf 
Triche, S. S. (2002). Preconceiving curriculum: An historical approach.

Tylor, R. W. (1957). "Curriculum then and now". In proceedings of 1956 Invitational conference on testing problems. Princeton, NJ: Educationla testing service.

Webb, N. L. (1997). Determining alignment of expectations and assessments in mathematics and science education. NISE Brief, 1(2). 